ECONOMICS

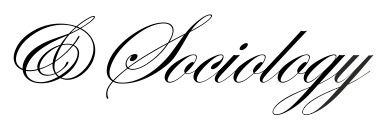

Małgorzata Wachowska,

University of Wroctaw,

Wrockaw, Poland,

E-mail:

malgorzata.wachowska@uwr.edu.pl

Received: September, 2017

1st Revision: December, 2017

Accepted: February, 2018

DOI: $10.14254 / 2071-$

789X.2018/11-1/20

\section{CONSEQUENCES OF THE POST- ACCESSION MIGRATION OF POLISH INVENTORS FOR THE INNOVATIVE POTENTIAL OF POLAND: 2004-2012}

JEL Classification: F22, J61, O15, O33

\begin{abstract}
The purpose of the paper is to answer the question what losses in the form of reduced ability to generate innovations - measured by the number of PCT inventions and the authors of these inventions - are incurred by Poland due to human capital outflow. The work uses the method of analyzing patent applications filed in the years 2004-2012 by the residents of the US, Japan, Germany, the UK, France, the Netherlands, Switzerland, Finland, Sweden, the Republic of Korea and China, regarding inventions that were created by the immigrants from Poland living in the aforementioned countries. The analysis of 1720 patent documents has shown that: (1) throughout the period under study Poland incurred losses in the form of 1720 PCT inventions that were mainly created for the benefit of the US, Germany and the UK; (2) losses for Poland were most visible in such areas as: chemistry; metallurgy; medicine; electricity and physics as well as in the business sector; (3) during the period under study the total of 830 PCT inventors left Poland, mainly for the US, Germany and the $\mathrm{UK}$, and the vast majority of them were men.
\end{abstract}

Keywords: innovations, inventions, migration, PCT patent applications, Poland

\title{
Introduction
}

Both political and economic discussions increasingly pay attention to the problems connected with human migration, which in many Eastern European countries, including Poland, intensified in the aftermath of their accession to the European Union (Grabowska-Lusińska, Okólski, 2008, 2009; Kaczmarczyk, 2015; Lesińska et al., 2014; Okólski, 2009). In particular, politicians in different countries are concerned with the outflow of more talented and skilled citizens because it results in a loss of their knowledge and skills, and this reduces the ability to absorb and generate innovations domestically.

Inventors may be considered part of the group of people characterized by the highest human capital and - as it is commonly argued - a special contribution into the creation of technical innovations. These technological changes are taking place in the world thanks to the authors of inventions filed for patent protection under the Patent Cooperation Treaty (PCT). The costs of obtaining an "international patent" - which can cover a vast number of countries 
- are disproportionately higher than the costs of protection under national or regional laws. It may therefore be assumed that applicants will chose the international procedure only if they themselves consider the economic and commercial potential of their invention to be high enough.

In the light of the above, the aim of this paper is to answer the question of what losses in the form of reduced ability to generate innovations - as measured by the number of PCT inventions and their authors - are incurred by Poland due to human capital outflow from this country.

The paper discusses several questions: (1) how many inventions, including also their breakdown by sectors and technological areas, do the Poles generate in the countries they migrate to? (2) what share of the entire inventive output of Poland do these inventions constitute? and (3) how many Polish authors of inventions, including also their breakdown by gender, live abroad?

In order to address these questions, PCT applications have been first analyzed with regard to the nationalities and places of residence of the inventions' authors. The analysis covers the applications from the countries accounting for the vast majority of international applications, i.e. the USA, Japan, Germany, the UK, France, the Republic of Korea and China as well as the countries showing a large number of these applications in relation to the total number of patent applications in these countries, i.e. the Netherlands, Switzerland, Finland and Sweden (Miguelez, Fink, 2013). Analysis of patent applications by the residents of the abovementioned countries has made it possible to separate those in the case of which the authors of technical inventions are the Poles living in these countries.

Subsequently - in order to answer the question of how many inventions and inventors, in absolute terms, Poland loses due to talents' outflow - the information provided in individual applications was analyzed. Doing this has made it possible to create a unique database covering patent applications filed by the residents of the countries covered by the analysis with characteristics of the inventions filed for protection and their authors - immigrants from Poland.

Finally, in order to estimate the losses incurred by Poland in relative terms, data from the created database have been compared with the number of patent applications filed under the same international procedure by Polish residents. Doing this has made it possible to determine what share of all Polish PCT inventions are the ones generated by the Poles living abroad, i.e. how many inventions Poland loses as compared to its domestic inventive output.

In total, out of PCT applications filed during 2004-2012 by the residents of the USA, Japan, Germany, the UK, France, the Republic of Korea, China, the Netherlands, Switzerland, Finland and Sweden, 1720 have been identified and analyzed. The analysis has covered all PCT inventors coming from Poland who were living in the abovementioned countries at the moment of filing the application but not all Polish inventors in general.

This study makes a contribution to the discussion on the role of the mobility of skilled workers in stimulating international transfers of knowledge by using the patent data of the World Intellectual Property Organization (WIPO) in order to determine the effects from the outflow of Polish inventors on the reduction in the innovation-generating potential of Poland. Most previous studies which have used patent data in this area have relied either on the statistics of national patent offices, or the data of the European Patent Office (EPO). In both cases it is not possible to explicitly determine the nationality of the authors of inventions because such information is not required by the patent application form. As a consequence, the authors of the studies identify the authors of inventions of a given nationality on the basis of ethnic origin of their surnames, which evidently distorts the final results of the studies. Contrary to this, most PCT applications which are administered by the WIPO provide the basis for explicit identification of the nationality of an author of a technical invention. 
Moreover, the majority of the studies addressing the problems of human capital migration as applied to the innovation and knowledge transfer processes focus mainly on one destination country - the US - and several countries of origin which are at present the largest sources of talent acquisition for the US, i.e., India and China as well as several other East Asian countries. Meanwhile, Central and Eastern Europe, including Poland, has been studied in this context rather fragmentarily.

Contrary to the above, this study - based on the PCT applications' data - has quite precisely determined the number of PCT inventions created by the Poles in various destination countries, i.e., the US, Japan, Germany, the UK, France, the Republic of Korea, China, the Netherlands, Switzerland, Finland and Sweden, which has also made it possible to determine how many inventions Poland potentially loses due to talents' outflow. Moreover, it has rather precisely determined the number of PCT inventors, broken down by nationalities of those living and creating abroad in the abovementioned countries. And this has, in turn, made it possible to determine how many inventors Poland loses due to migration.

\section{Literature review}

Given how many studies exist on international human migration and international transfers of knowledge, there are surprisingly few analyses linking both these phenomena. The literature on the contribution of mobile human capital to the international transfer of knowledge and, consequently, to the increases in inventiveness of economies is relatively scarce - although since 1990s it has been growing (Kapur, 2001) - and to a larger extent it focuses on transfers of knowledge from the home country to the host country of a migrant and consequently on their effects for the destination country in the form of greater innovativeness rather than on the effects for the country of origin of the migrant.

The effects of highly-skilled emigration on the level of innovation of countries of origin tend to be discussed from the perspective of two phenomena. On the one hand, the role of immigrants creating diasporas is studied in transferring their knowledge and skills acquired abroad to their home countries through private networks, programs of $R \& D$ cooperation between entities from different countries or provision of consulting services for businesses from their home country (Agrawal et al., 2008; Meyer, 2001; Nanda, Khanna, 2010; Saxenian, 2005). On the other hand, the direct contribution of scientists or engineers returning from emigration is studied, who either start businesses in their home countries or take jobs in local organizations (Filatotchev et al., 2011; Jonkers, Tijssen, 2008; Kenney et al., 2013; Wang, 2015).

The majority of these works, however, are case studies of individual migrants and individual workplaces (Meyer, 2001; Nanda, Khanna, 2010; Filatotchev et al., 2011; Boncea, 2015), while there are few quantitative studies, also those which use patent data (Agrawal et al., 2008; Azoulay et al., 2011; Breschi et al., 2015).

The relationship between citizens living abroad and the innovativeness of their home counties was investigated, among others, by Saxenian (2002, 2005), who studied the contribution of skilled Asian immigrants (mainly from China and India) working in Silicon Valley in the US to enterprise creation as well as trade and investment facilitation and also to the development of computer industry in their countries of origin. The evidence of the existence of positive effects on the sending economy was also found by Agrawal et al. (2008), who with the use of patent data - found that emigrating innovators from India had contributed to the creation of the most significant inventions of their country, alba it in net terms they "hindered" the access to knowledge for individuals who remained in India. Also on the basis of patent data, Kerr (2008) found that immigrants in the US, especially those from China, facilitated knowledge flows to their home countries; Oettl and Agrawal (2008) proved that mobile inventors were sources of feedback for companies and countries they had left; and Breschi et 
al. (2015) found that immigrants from China, South Korea and Russia living in the US contributed to transferring knowledge to their home countries. Meanwhile, on the basis of survey studies, Ciumasu (2010) found that almost half of Romanian scientists emigrating to the top universities in the world co-operated with their compatriots who had remained in their countries and $95 \%$ were interested in such co-operation.

So far as the relationship between the return migration and the innovativeness of a country is concerned, it was the subject of analyses, among others, by Jonkers and Tussen (2008), Murakami (2014) and Marmolejo-Leyva et al. (2015), who focused on the role of mobile individuals in promoting international scientific co-operation. Jonkers and Tussen (2008), on the basis of publication analysis, found a positive relationship between Chinese researchers returning from abroad and their $\mathrm{R} \& \mathrm{D}$ co-operation with their colleagues from host countries. Also on the basis of publication analysis, Murakami (2014) found that return migration of Japanese scientists only to a small extent promoted research co-operation undertaken with foreigners in the US. Meanwhile Marmolejo-Leyva et al. (2015) found a strong relationship between the emigration of Mexican researchers to the US, the UK, Germany, France, Spain, Canada and Brasil and their international scientific co-operation upon return to their country, especially in life sciences, physics and engineering.

Migrants returning to their countries contribute to their development not only by maintaining research relationships with the host country. It appears from the survey studies by Edler et al. (2011) that mobile German scientists transfer know-how acquired during their stay abroad to enterprises located in Germany. Wang (2015) comes to similar conclusions, also on the basis of survey studies, and finds that individuals returning from the US transfer organizational knowledge to their home countries. Meanwhile survey studies by Liu et al. (2010) suggest that businesses created by the Chinese returning from emigration are more innovative than local ones and they are also a source of knowledge for local competitors. Similarly, Krabel et al. (2012) concluded that mobile German scientists (more often than immobile ones) become innovative entrepreneurs upon their return to their country. Filatotchev et al. (2011) found in turn a positive relationship between returning migrants of Chinese origin and the productivity of small and medium enterprises from China.

Among the above mentioned works, however, only the analysis by Brechi et al. (2015) relies on PCT patent data in order to identify immigrants, which currently offers the best precision in determining the ethnic origin of a mobile individual (see the next section). Although there are other studies than Breschi et al. (2015) which use PCT patent data to determine the origin of mobile inventors, they focus on either determining the size of international migration flows, with Poland not being their main point of interest (Miguelez, Fink, 2013), or on determining the extent of international patent co-operation (Miguelez, 2014).

\section{Methodological approach. Patent statistics in studying the effects of human capital migration}

Data and information included in patent applications may be used in studies addressing the problems of $R \& D$ cooperation, human migration, knowledge transfers and innovative activity of, for instance, enterprises. Questions related to innovativeness of entities and diffusion of knowledge are often treated jointly because the amount of knowledge transfers is measured, among other things, from the perspective of their effects, and one particularly important effect of know-how diffusion is notably an increase in the level of innovativeness. Similarly, questions of R\&D cooperation and knowledge transfer are often combined. Research cooperation is in a natural way associated with knowledge diffusion since the main motive for undertaking joint activities by individual entities is intended acquisition and use of know-how of others. 
Patent applications contain information that makes it possible to deal, at least to some extent, with all of the above questions. It includes, among other things, the name and surname or the company name of the owner of the invention (the applicant), which makes it possible to determine the cooperating parties, if there is more than one owner, as well as the sectors of economy where these parties belong (e.g. science, business). Every patent application includes also information on the technological area of the invention, i.e. it is possible to determine not only the number of inventions generated by applicants of our interest but also their innovative activities in particular areas. Knowledge diffusion, meanwhile, can be inferred, besides linking it to innovative activity or R\&D cooperation, from so-called citations (references of the authors of inventions to the knowledge of their predecessors) included in patent applications. Since it is possible to identify the owners of patents or publications that the authors of inventions cite in their patent application, it also becomes possible to determine the directions and the extent of knowledge flows.

Patent data also make it possible to track migration paths of inventors, although it tends to be a difficult task. Patent documents include, besides the applicants, also the names and surnames of the authors of inventions as well as their places of residence. So, if we find that e.g. the author of the invention in a patent application of an American resident is a Pole living in the US then we can at the same time determine the geographical direction of migration of the Polish inventor, the number of inventions he created while abroad as well as which technological area and sector of economy these inventions come from. On the basis of information recorded in patent documents it is therefore possible to determine not only the volume and directions of migration of inventors but also the size of their inventive output. Unfortunately, the researchers face the difficulty of explicit identification of inventors' nationalities. In the vast majority of cases it is not required to reveal nationalities of the authors of inventions in patent forms, which results in the nationality of the inventor being identified on the basis of ethnic origin of their surname. This obviously can lead to many errors.

Therefore, knowledge stocks of WIPO, which has developed the PCT patent application form, are particularly valuable in research on migration of inventors and the effects of their work. Similarly, as in other applications of this type, PCT applications include both the place of residence and the nationality of applicants. Contrary to other applications of this type, however, until recently there had been a requirement to also include all creators of the invention in the field pertaining to the applicant, which consequently resulted in the necessity to reveal their nationality.

Unfortunately, because of changes in the US patent law introduced on January 1st, 2012, only few PCT applications filed after that date include the nationality of the authors of inventions (Miguelez, Fink, 2013) since only few authors of inventions are added to applicants. The US under the Leach-Smith America Invents Act (AIA) have cancelled the requirement to list inventors as applicants in those PCT applications in which the US are indicated as the socalled designated state in the application (i.e. the country in which the applicant considers seeking patent protection). It is the applicant's decision whether to name inventors together with the applicant. In practice, the majority of applicants have taken the opportunity not to list the authors of inventions among the applicants. If we take into account that the coverage of a vast majority of "international patents" includes the US, after 2012 PCT patents have become definitely less useful in research on human migration and its role in processes of knowledge transfer.

Despite its many advantages, migration studies that use patent data, including the analyses addressed in this paper, have their limitations. First of all, they only permit to formulate conclusions with regard to the number of inventors from various parts of the world living in a given year in a given country but they do not make it possible to explicitly determine the year in which the inventor left their country. For instance, in a group of Polish inventors living 
abroad who e.g. in 2004 created an invention and filed it for patent protection (which stems from patent documentation) there may be persons who emigrated from Poland in earlier periods. Additionally, patent documents permit to determine only the citizenship of an inventor, which means that in studies using patent data the long term migrants who have already been granted the citizenship of their destination country may be omitted.

This study uses WIPO knowledge stocks to determine the number of inventions generated by Poles and the number of inventors themselves living abroad in years 2004-2012, which makes it possible to overcome the limitations related to data after 2012. Moreover, in order to calculate the size of the population of Polish inventors abroad in individual years, the paper makes the assumption that a Polish inventor in a given year lived abroad in a given country even if this does not follow from the patent documents (i.e. in the year under analysis he or she did not file any patent application), under the condition that he or she was inventively active in the same country in both preceding and subsequent years, which follows from patent applications.

\section{Lost inventions: research results}

The analysis of PCT patent documents has shown that Poles as a nation are rather active inventively abroad. In years 2004-2012 in the European countries under analysis (Germany, the UK, the Netherlands, Switzerland, France, Sweden, Finland), the US and Asian countries under analysis (Japan, China, the Republic of Korea) they created a total of 1720 PCT inventions (Table 1), i.e. 307 more than the number of analogical inventions over the same period domestically.

Table 1. The number of PCT inventions authored or co-authored by immigrants from Poland, in selected host countries

\begin{tabular}{ccccccccccccc}
\hline & CH & DE & FI & FR & GB & NL & SE & US & JP & CN & KR & Total \\
\hline 2004 & 9 & 23 & 1 & 2 & 10 & 12 & 3 & 64 & 2 & 0 & 0 & 126 \\
\hline 2005 & 3 & 29 & 0 & 3 & 7 & 19 & 3 & 82 & 3 & 0 & 0 & 149 \\
\hline 2006 & 6 & 38 & 0 & 7 & 12 & 24 & 1 & 90 & 2 & 0 & 0 & 180 \\
\hline 2007 & 5 & 50 & 4 & 7 & 10 & 16 & 2 & 108 & 4 & 0 & 0 & 206 \\
\hline 2008 & 8 & 55 & 5 & 5 & 23 & 11 & 0 & 115 & 0 & 0 & 0 & 222 \\
\hline 2009 & 8 & 82 & 2 & 8 & 16 & 12 & 2 & 131 & 4 & 0 & 0 & 265 \\
\hline 2010 & 11 & 79 & 6 & 5 & 12 & 7 & 7 & 81 & 1 & 2 & 0 & 211 \\
\hline 2011 & 10 & 51 & 3 & 12 & 23 & 7 & 12 & 04 & 4 & 0 & 0 & 216 \\
\hline 2012 & 9 & 18 & 1 & 8 & 30 & 9 & 3 & 63 & 4 & 0 & 0 & 145 \\
\hline Total & 69 & 425 & 22 & 57 & 143 & 117 & 33 & 828 & 24 & 2 & 0 & 1720 \\
\hline
\end{tabular}

Source: own work and calculations based on an analysis of PCT patent documents.

It is worth noting here that it is not only Poles who are more creative abroad than in their home country. Behavior patterns of this kind are quite typical of the citizens of many countries of Central and Easter Europe or generally of developing countries, e.g. Mexico. For instance, the inventive output of mobile Poles on behalf of only the United States accounts on average for $49 \%$ of the number of PCT inventions created on behalf of the home country while it is $53 \%$ in the case of mobile Slovaks and $81 \%$ in the case of mobile Ukrainians. Among the countries of Central and Eastern Europe, relatively few PCT inventions, in comparison to the number of analogous inventions filed for protection on behalf of the home countries, are created on behalf of the host countries by Czechs, Hungarians and Lithuanians. 
The country in which the work of Poles is most visible is the US, where immigrants from Poland created 828 inventions over the whole period under study. Polish inventors have also made their presence visible in three European countries - Germany, the UK and the Netherlands - creating there a total of 425, 143 and 117 inventions, respectively, during the period under study (Table 1). The contribution of Poles to the innovative output of Asian countries under study - Japan, China and the Republic of Korea - is limited, meanwhile, to a mere 26 technical solutions: 24 in Japan and 2 in China.

Generally, in both Europe (the total for European countries under analysis) and the US, the trend in the number of filed PCT applications in which a Pole was the author of the invention showed a rising tendency until 2009, whereas in the subsequent years the number of inventions created by Poles visibly decreased (Graph 1). However, whereas until 2009 it was the US that to a larger degree had benefited from Polish presence, in the subsequent years it was in Europe where the larger quantity of inventions created by Poles could be observed. So far as Asian countries are concerned, the number of PCT inventions created there by immigrants from Poland was at a similar and low level throughout the whole period under study (Graph 1).

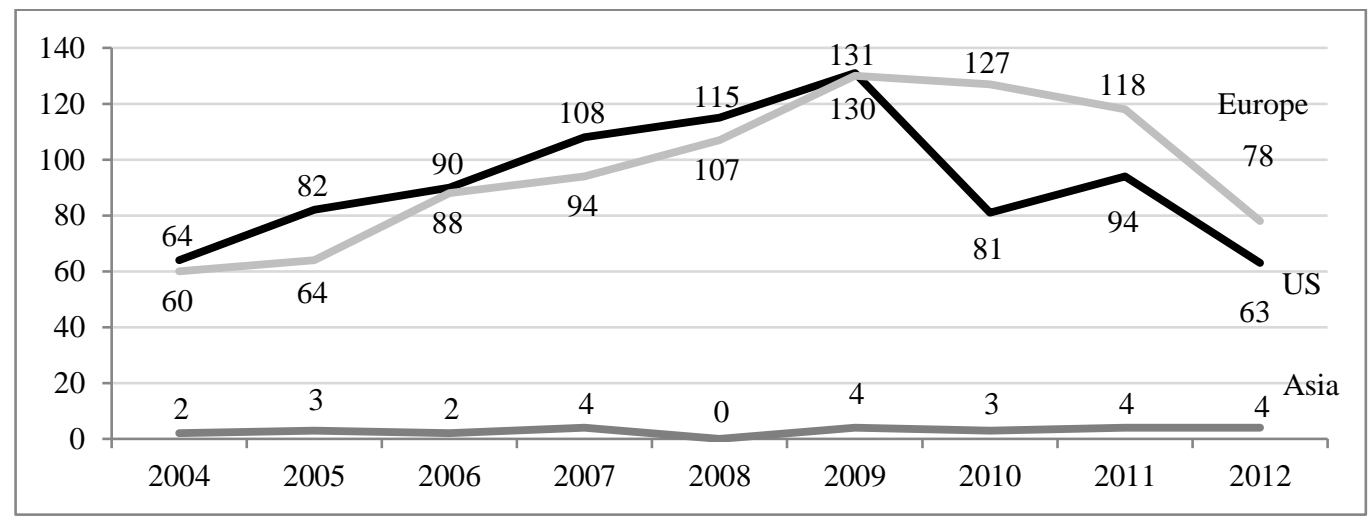

Graph 1. The number of PCT inventions authored and co-authored by immigrants from Poland, in individual years in the US, European countries and Asian countries

Source: own work and calculations based on an analysis of PCT patent documents.

Like abroad, Polish PCT inventors create on behalf of their country mainly inventions classified in the area of technics: (1) human necessities (24.44\%), also including mainly the area of medicine $\left(60.54 \%\right.$ of these) as well as (2) chemistry; metallurgy $(21.53 \%)^{1}$. This may be evidence that migration of Polish PCT inventors is rather pushed by supply than pulled by demand since it results mainly from the desire of mobile individuals to make use of their own advantages and skills than to fill the skills gap in destination countries.

So far as the structure of PCT inventions created by Poles living abroad is concerned, the majority of these (33.99\%) is classified in the area of technics: chemistry; metallurgy. Poles generate also inventions classified as: (1) human necessities $(23.25 \%)$, including mainly the area of medicine $(85.29 \%$ of these), (2) electricity $(17.50 \%)$, (3) physics $(11.42 \%)$ as well as (4) performing operations; transporting $(9.87 \%)$. The smallest share of the inventive output of immigrants of Polish origin, barely $0.62 \%$, are solutions classified as fixed constructions (Graph 2).

\footnotetext{
${ }^{1}$ Own calculations based on WIPO statistics database. https://www3.wipo.int/ipstats/pmhindex.htm?tab=pct (referred on 18/08/2017).
} 


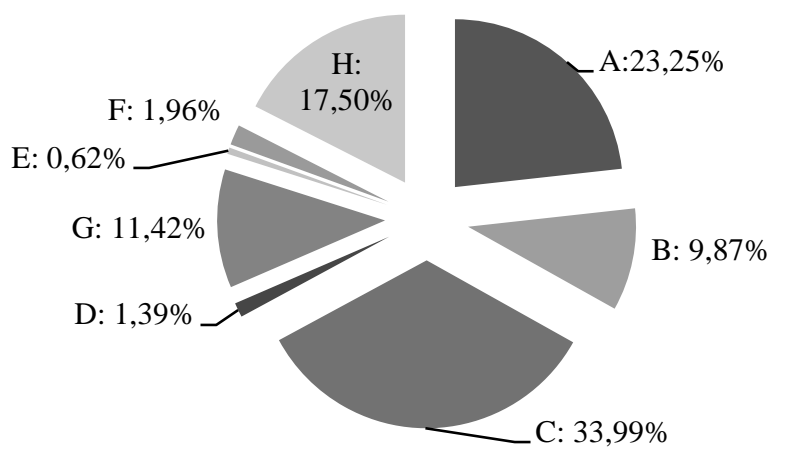

Legend: A: Human necessities; B: Performing operations; Transporting; C: Chemistry; Metallurgy; D: Textiles; Paper; E: Fixed constructions; F: Mechanical engineering; Lighting; Heating; Weapons; Blasting; G: Physics; H: Electricity.

Graph 2. The structure of PCT solutions authored or co-authored by immigrants from Poland, by the areas of technology of the International Patent Classification (2004-2012)

Source: own work and calculations based on an analysis of PCT patent documents.

In none of the host countries Polish immigrants specialize in areas that are to a largest degree avoided by locals, nor - as a rule - do they create a greater number of inventions in those areas in which also local inventors are mainly active, albeit there are clear differences between the research activity of Polish inventors in particular destination countries. In Germany, the United Kingdom, Switzerland and France, the majority of PCT applications filed by Poles concern chemistry and metallurgy, in the United States it is medicine, in the Netherlands physics, while in Sweden, Finland and Japan electricity (Table 2).

Table 2. Structure of PCT inventions created by Poles in selected host countries, by the areas of technology of the International Patent Classification (2004-2012)

\begin{tabular}{cccccccccc}
\hline & $\mathrm{A}$ & $\mathrm{B}$ & $\mathrm{C}$ & $\mathrm{D}$ & $\mathrm{E}$ & $\mathrm{F}$ & $\mathrm{G}$ & $\mathrm{H}$ & \\
\hline $\mathrm{US}$ & $36,44 \%$ & $3,85 \%$ & $30,91 \%$ & $0,43 \%$ & $0,62 \%$ & $1,12 \%$ & $9,87 \%$ & $16,76 \%$ & $100 \%$ \\
\hline $\mathrm{DE}$ & $13,33 \%$ & $14,96 \%$ & $46,12 \%$ & $1,94 \%$ & $0,15 \%$ & $1,86 \%$ & $6,51 \%$ & $15,13 \%$ & $100 \%$ \\
\hline $\mathrm{GB}$ & $22,09 \%$ & $15,72 \%$ & $29,38 \%$ & $0,91 \%$ & $0,68 \%$ & $5,01 \%$ & $12,53 \%$ & $13,68 \%$ & $100 \%$ \\
\hline NL & $16,20 \%$ & $3,17 \%$ & $11,27 \%$ & $0,70 \%$ & $0 \%$ & $0,35 \%$ & $42,60 \%$ & $25,71 \%$ & $100 \%$ \\
\hline $\mathrm{CH}$ & $26,79 \%$ & $6,70 \%$ & $39,23 \%$ & $0 \%$ & $0,48 \%$ & $8,13 \%$ & $10,05 \%$ & $8,62 \%$ & $100 \%$ \\
\hline FR & $11,58 \%$ & $25,87 \%$ & $42,47 \%$ & $5,02 \%$ & $4,25 \%$ & $0 \%$ & $4,63 \%$ & $6,18 \%$ & $100 \%$ \\
\hline SE & $16,48 \%$ & $0 \%$ & $10,99 \%$ & $0 \%$ & $0 \%$ & $0 \%$ & $21,98 \%$ & $50,55 \%$ & $100 \%$ \\
\hline FI & $0 \%$ & $2,00 \%$ & $0 \%$ & $0 \%$ & $0 \%$ & $6,00 \%$ & $16,00 \%$ & $76,00 \%$ & $100 \%$ \\
\hline JP & $3,19 \%$ & $12,76 \%$ & $15,96 \%$ & $9,57 \%$ & $0 \%$ & $0 \%$ & $14,89 \%$ & $43,61 \%$ & $100 \%$ \\
\hline
\end{tabular}

Legend: symbols from A to H: see Graph 2.

Source: own work and calculations based on the analysis of PCT patent documents.

In terms of sectors, the vast majority of the inventive output of Poles abroad belongs to businesses $(81.04 \%)$ and only $13.95 \%$ to the area of science, although also in this case differences may be observed between particular countries of destination. The research activity of Polish inventors in the business sector is most visible in Japan and Sweden, where as many as $100 \%$ and $96.97 \%$ of the filed PCT applications, respectively, belong to business. At the same time, inventions in the area of science are definitively more scarce. Their share in the total 
number of PCT applications ranges from 0\% in Sweden and Japan to 23.33\% in France and $27.5 \%$ in Switzerland (Table 3).

Table 3. The sectoral structure of PCT inventions created by Poles in selected host countries (2004-2012)

\begin{tabular}{lccccccccc}
\hline & US & DE & CH & FI & FR & GB & NL & SE & JP \\
\hline Science & $18,59 \%$ & $4,58 \%$ & $27,5 \%$ & $4,54 \%$ & 23,33 & $18,06 \%$ & $4,24 \%$ & $0 \%$ & $0 \%$ \\
\hline Business & $72,29 \%$ & $94,74 \%$ & $68,75 \%$ & $95,46 \%$ & $76,67 \%$ & $80,64 \%$ & $94,07 \%$ & $96,97 \%$ & $100 \%$ \\
\hline $\begin{array}{l}\text { Other } \\
\text { sectors }\end{array}$ & $9,12 \%$ & $0,68 \%$ & $3,75 \%$ & $0 \%$ & $0 \%$ & $1,30 \%$ & $1,69 \%$ & $3,03 \%$ & $0 \%$ \\
\hline & $100 \%$ & $100 \%$ & $100 \%$ & $100 \%$ & $100 \%$ & $100 \%$ & $100 \%$ & $100 \%$ & $100 \%$ \\
\hline
\end{tabular}

Source: own work and calculations based on an analysis of PCT patent documents.

Finally, the majority of inventions (68.64\%) that increase knowledge stocks of destination countries are created by men of Polish origin and only $31.36 \%$ by women. Notably, women are more innovatively active in France, the US and the UK and as a result they create there a relatively large share of PCT inventions $(48,27 \%, 35,30 \%, 31,41 \%$, respectively) the authors of which are Poles, whereas the contribution of men is the most evident in Japan and Finland, where, respectively, $100 \%$ and $95.46 \%$ of the innovative output created by Poles is the effect of work of men.

The above results concerning absolute numbers indicate therefore that the steady growth of global flows of scientists, engineers and highly skilled specialists from developing countries to developed countries, including Polish inventors, is accompanied by decreasing ability to absorb and generate innovation in Poland, which in years 2004-2012 lost potentially 1720 inventions with high economic potential, in the areas of medicine and electricity, and which moreover originated mainly from the business sector, which in Poland accounts for a significantly lower number of inventions than academic centers.

These losses are even greater if it is taken into account that the number or PCT inventions created in years 2004-2012 by Poles abroad for the benefit of host countries (1720) is larger than ones created domestically (1413) and constitutes more than $120 \%$ of Polish PCT inventions. A promising phenomenon for Poland, however, is that beginning from 2010 the number of Polish PCT inventions started to exceed ones created by Poles abroad for the benefit of their countries of destination (Graph 3). This may indicate that Polish researchers have been returning home and at the same time contributing to an increase in top quality inventive activity or that some mechanisms have been developed owing to which knowledge diffusion takes place from Polish diasporas and consequently also an increase in creative productivity of inventors who had remained in their home country.

Comparing the number of inventions created by immigrants from Poland with ones generated in their home country makes it possible to determine losses for Poland related to the loss of „brains” in relative terms. Namely, Poland had incurred the greatest losses until 2007 when PCT inventions created by Poles leaving the country reached the highest level of $192.52 \%$ of analogous inventions generated domestically. In subsequent years, the difference between foreign and domestic inventions of Poles systematically decreased and ultimately in 2012 the number of inventions generated abroad constituted $57.77 \%$ of those generated domestically.

Also in the relative terms, albeit in the relation to the type of inventions, losses due to the outflow of talents are most affect Poland in electricity; chemistry and metallurgy as well physics. Inventions created by Poles abroad in the above mentioned areas constitute, respectively, $664,03 \%, 348,58 \%$ and $236,36 \%$ of PCT patent applications filed in these areas 
by Polish residents. Meanwhile, the emigration of inventors specializing in fixed constructions or in the following areas: mechanical engineering, lightning, heating, weapons, blasting least affects Poland because PCT inventions in these areas created by Poles abroad constitute mere $16.98 \%$ and $35.42 \%$ of Polish PCT inventions in the same areas, respectively.

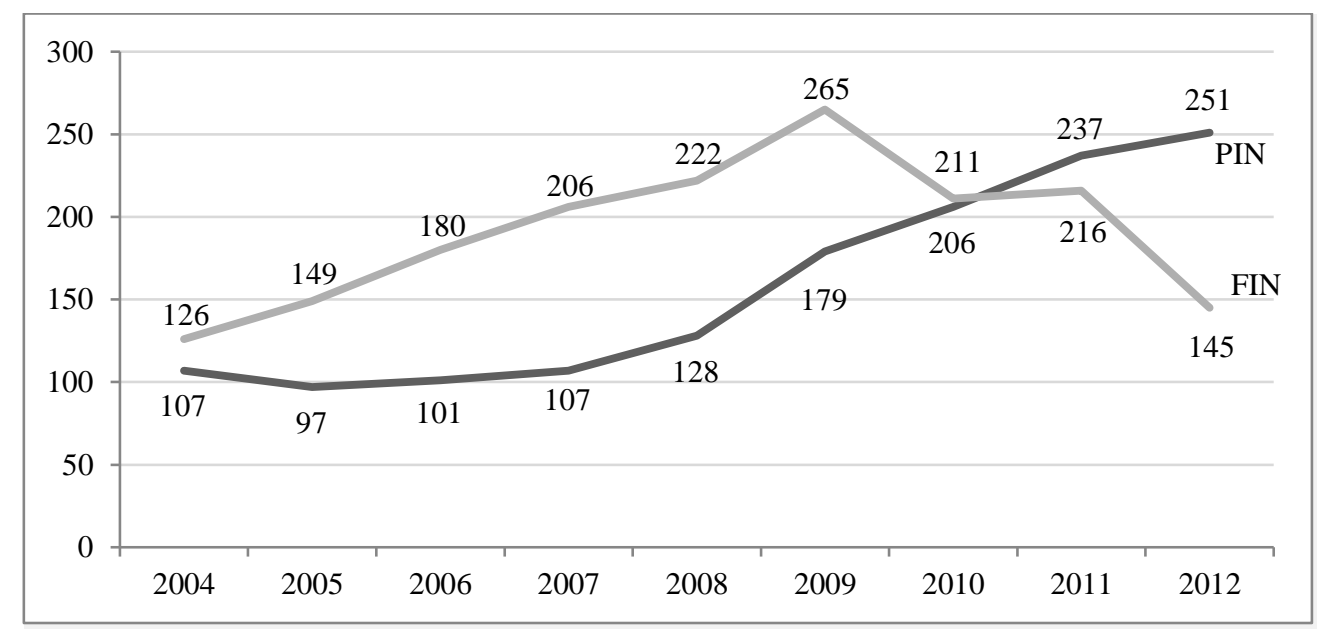

Legend: PIN - Polish PCT inventions; FIN - PCT inventions created by Poles in emigration countries of destination.

Graph 3. The number of Polish PCT inventions and PCT inventions created by Poles for the benefit of host countries (2004-2012)

Source: own work based on an analysis of PCT patent documents and based on the database WIPO: Statistical Country Profiles, http://www.wipo.int/ipstats/en/statistics/country_profile/profile.jsp?code=PL, retrieved February 11, 2017.

\section{Lost human capital: research results}

The analysis of PCT patent documents has shown that in years 2004-2012, a total of 830 Polish PCT inventors have lived abroad in 11 countries covered by the study, with not all of them living in their host countries throughout all this period. It should be noted here that although the number of immigrant inventors of Polish origin is not large, neither in absolute terms nor per either the total number of Polish citizens or only mobile ones, Poles do not look bad in comparison to the region or many other countries. In absolute terms, the most numerous groups of mobile inventors are citizens of China, India, Canada, the United Kingdom and Germany (Miguelez, 2014). So far as non-OECD countries that are the most numerous sources of origin of immigrant inventors are concerned, these are - apart from China and India - Russia, Turkey, Iran, Romania, Mexico, Malaysia and Ukraine (Miguelez, 2014). However, if relative numbers were taken into account, places in the ranking of the largest suppliers of inventions would change in some cases. For instance, each year in 2008-2012 on average $11.57 \mathrm{mln}$ of immigrants from Mexico lived in the United States (OECD.Stat), of which ca. $104^{2}(0.0009 \%)$ were creators of PCT inventions, whereas the number of Poles living in the same time in the United States was only 457.31 thousand on average each year (OECD.Stat), of which 81 (0.018\%) were PCT inventors (Wachowska, 2017).

\footnotetext{
${ }^{2}$ Own calculations.
} 
The largest group among the researchers covered by the analysis were Polish inventors living in the US (346), Germany (209) and the UK (108), which generally reflects the distribution of the number of inventions created in these countries by Poles (Graph 4).

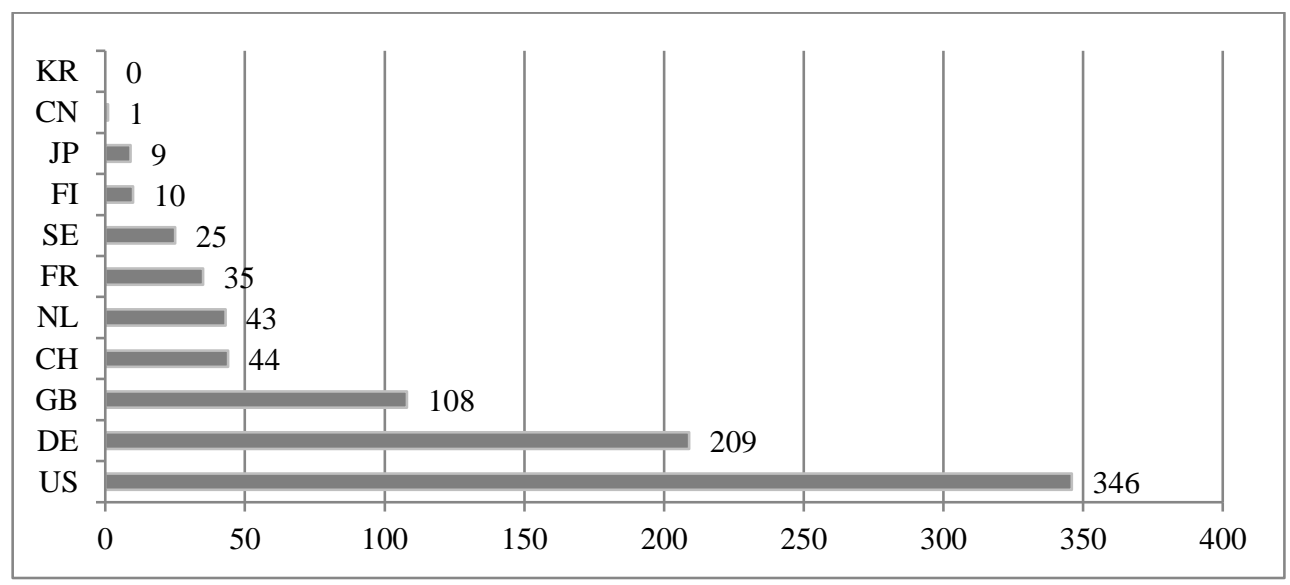

Graph 4. The number of Polish PCT inventors in selected countries (2004-2012) Source: own work and calculations based on an analysis of PCT patent documents.

Similarly to the number of inventions created by Poles living abroad, also in the case of the authors themselves of these inventions, a decreasing trend could be observed from 2008, both for Polish inventors in total and separately from the European countries under study and the US, with the decrease in the number of immigrants-inventors living in the US having been significantly larger (Graph 5, Table 4). In fact, the number of Polish inventors living abroad decreased in 2012 to the level observed in 2005.

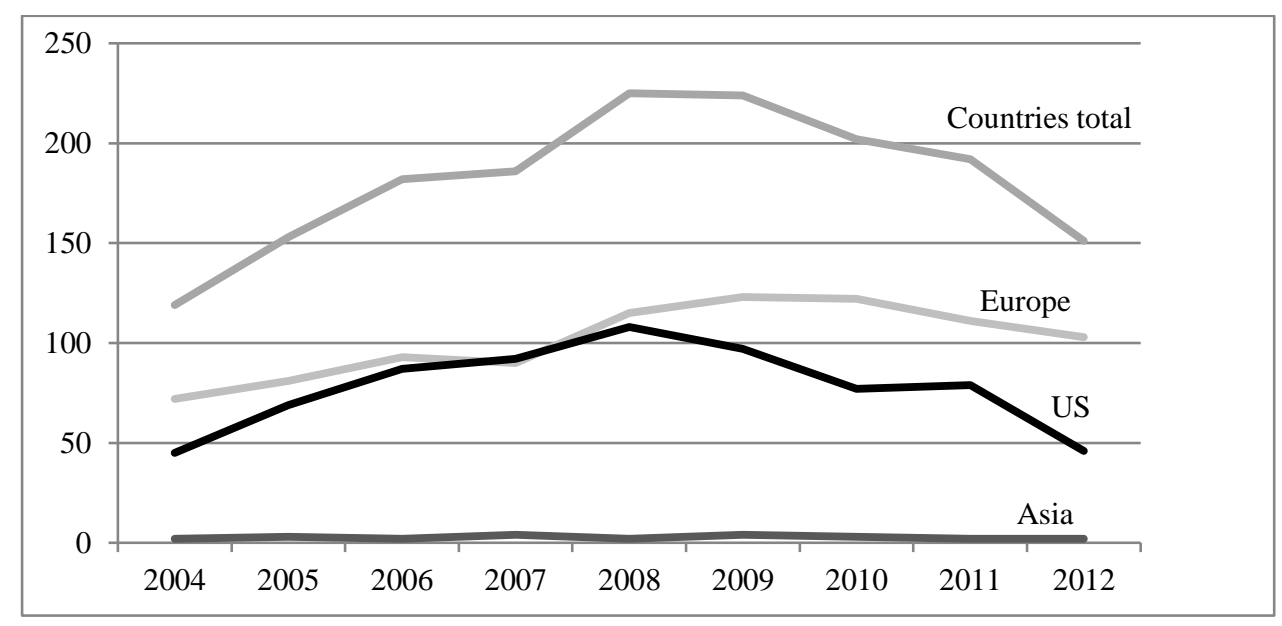

Graph 5. Geographical distribution of Polish PCT inventors

Source: own work and calculations based on an analysis of PCT patent documents.

A significant decrease in the number of Polish inventors living abroad, and the accompanying decrease in the number of PCT inventions they have created abroad that has been taking place since 2008, should be associated with the global economic crisis. It is surprising, however, that contrary to expectations, it has to a larger degree affected the group of better educated Poles. Unlike in the case of PCT inventors, however, the total number of 
Poles living abroad increased from 2008 to 2011, with the small decreasing tendency visible in 2012 only (OECD.Stat).

So far as the gender of inventors leaving Poland is concerned, as many as $72.77 \%$ are men and only $27.23 \%$ are women, with the share of women ranging from $0 \%$ to $39.53 \%$ depending on the country of destination. The largest percentage of women among Polish inventors may be observed in the Netherlands (39.53\%), France (37.14\%) and the UK $(32.41 \%)$, whereas the fewest women - in relative terms - were living in Asian countries covered by the study (0\%) as well as Sweden (20\%) and Finland (20\%). It is noteworthy that although in the US - against the background of other countries included in the analysis - Polish women make a significant contribution to the innovative output of this country, they do not constitute a large - in comparison to other countries - percentage of inventors. Their presence in the US is limited to mere $27.46 \%$ of all Polish immigrants-inventors in this country, which is only slightly above the average for all the countries covered by the analysis.

Table 4. Geographical distribution of Polish PCT inventors*

\begin{tabular}{cccccccccc}
\hline & 2004 & 2005 & 2006 & 2007 & 2008 & 2009 & 2010 & 2011 & 2012 \\
\hline CH & 6 & 9 & 8 & 9 & 13 & 10 & 8 & 7 & 8 \\
\hline DE & 35 & 34 & 41 & 41 & 53 & 58 & 58 & 49 & 45 \\
\hline FI & 1 & 0 & 0 & 2 & 3 & 4 & 4 & 4 & 1 \\
\hline FR & 8 & 9 & 11 & 7 & 7 & 6 & 6 & 7 & 7 \\
\hline GB & 10 & 12 & 17 & 16 & 25 & 27 & 26 & 25 & 31 \\
\hline NL & 6 & 10 & 11 & 9 & 9 & 11 & 11 & 9 & 8 \\
\hline SE & 6 & 7 & 5 & 6 & 5 & 7 & 9 & 10 & 3 \\
\hline US & 45 & 69 & 87 & 92 & 108 & 97 & 77 & 79 & 46 \\
\hline JP & 2 & 3 & 2 & 4 & 2 & 4 & 2 & 2 & 2 \\
\hline CN & 0 & 0 & 0 & 0 & 0 & 0 & 1 & 0 & 0 \\
\hline Total & 119 & 153 & 182 & 186 & 225 & 224 & 202 & 192 & 151 \\
\hline
\end{tabular}

* The total number of inventors for 2004-2012 does not sum up with the number of inventors in particular years. It is because one inventor can live in a given country for several years. Hence the total number of inventors in 2004-2012 in particular countries in Graph 4 and in particular regions of the world in Graph 5 is different than the sum of inventors from particular countries in years from 2004 to 2012 in Table 4.

Source: own work and calculations based on an analysis of PCT patent documents.

\section{Conclusion}

In 2004-2012, a total of 830 inventors left Poland to create, for the benefit of the countries they emigrated to, a yearly average of 191 inventions - mainly in chemistry, metallurgy, medicine, electricity and physics - of the top economic potential, i.e. ones filed for patent protection under international procedure (PCT inventions). Their work was most visible in the US, Germany, the UK and the Netherlands and, in each of these as well as in other countries included in the study, in the business sector.

The loss within 9 years of 830 persons with the top human capital and 1720 inventions together with them is undoubtedly large, especially that the number of PCT inventions created yearly by Poles abroad exceeds ones created domestically by 34 , thus constituting on average more than $120 \%$ of all PCT inventions created and filed by Polish residents. It should be emphasized, however, that both the number of inventions created by Poles abroad and the number of their authors was not distributed evenly over the period of those 9 years, initially showing a rising tendency and then a significantly decreasing one. As early as 2007, the number of PCT inventions generated by Poles abroad in relation to Polish PCT inventions began to decrease, from 2010 Poles in Poland began to create a larger number of PCT inventions than 
abroad, and from 2008 also the number itself of inventors living abroad began to decrease to reach the level of year 2005 in 2012.

The results provided above show therefore that although the outflow of the most valuable human capital, i.e. PCT inventors, is not without influence on the innovative potential of Poland and that many economists and politicians are right to be concerned about further possibilities of development of knowledge-based economy in Poland without its most talented citizens, on the other hand they provide the basis for relieving some anxiety connected with emigration of educated Poles. Namely, they show that despite increasing openness of national economies and growing possibilities to live and work abroad and, consequently, increasing emigration of Poles to other countries, including also highly educated ones, the effect of these on the innovative potential of Polish economy is decreasing. Therefore, possible failures in the improvement of innovativeness in Poland should not be disproportionately linked to the „escape” of Poles to other countries.

The results of this analysis may be useful for future research, which could be focused on the causes of, on the one hand, decreasing inventive activity of Poles abroad, and on the other hand, increasing one at home; and in particular on settling the question whether the decreasing contribution of Polish immigrants to the inventive output of their host countries is a result of decreasing skills and creative potential of Poles which results in their share of research work being replaced by other nations or it is the consequence of Poles returning to their home country which results in increasing stocks of Polish PCT inventions. An answer to this question would make it possible to estimate potential future losses for Poland due to the outflow of talents and eventually revaluate the innovation policy of the country.

In the case of the first variant - decreasing skills of Poles - the policy actions should be to a larger extent oriented towards increasing quality on each level of education and not only the rate of scholarization alone as well as towards creating conditions and mechanisms conducive to transferring know-how - acquired in the host country - from migrants to the home country. In the case of the second variant, meanwhile, the state should create favorable conditions for domestic R\&D works.

\section{References}

Agrawal, A., Kapur, D., McHale, J. (2008). Brain drain or brain bank? The Impact of Skilled Emigration on Poor-Country Innovation. NBER Working Paper Series, 14592.

Azoulay, P., Graff Zivin, J. S., Sampat, B. N. (2011). The Diffusion of Scientific Knowledge Across Time and Space: Evidence from Professional Transitions for the Superstars of Medicine. NBER Working Paper Series, 16683.

Boncea, I. (2015). Turning Brain Drain into Brain Gain: Evidence from Romania's Medical Sector. Procedia Economics and Finance, 20, 80-87.

Breschi, S., Lissoni, F., Miguelez, E. (2015). Foreign Inventors in the US: Testing for Diaspora and Brain Gain Effects. GREThA Working Paper, 2015-25.

Ciumasu, I. M. (2010). Turning Brain Drain into Brain Networking. Science and Public Policy, $37(2), 135-146$.

Edler, J., Fier, H., Grimpe, Ch. (2011). International Scientist Mobility and the Locus of Knowledge and Technology Transfer. Research Policy, 40(6), 791-805.

Filatotchev, I., Liu, X., Lu, J., Wright, M. (2011). Knowledge Spillovers through Human Mobility across National Borders: Evidence from Zhongguancun Science Park in China. Research Policy, 40(3), 453-462.

Grabowska-Lusińska, I. (2009). Emigracja ostatnia? Warszawa: Wydawnictwo Naukowe Scholar. 
Grabowska-Lusińska, I., Okólski, M. (2008). Migracja z Polski po 1 maja 2004 r.: jej intensywnośći kierunki geograficzne oraz alokacja migrantów na rynkach pracy krajów Unii Europejskiej. CRM WorkingPapers, 33/91.

Jonkers, K., Tussen, R. (2008). Chinese Researches Returning Home: Impacts of International Mobility on Research Collaboration and Scientific Productivity. Scientometrics, 77(2), 299-323.

Kaczmarczyk, P. (2015). Poland: Large migration outflows and skill-mismatch. In: A. Schellinger (ed.), Brain drain - brain gain: European labour markets in times of crisis (pp. 33-43). Bonn: Friedrich-Ebert-Stiftung.

Kapur, D. (2001). Diasporas and Technology Transfer. Journal of Human Development, 2(2), 265-286.

Kenney, M., Breznitz, D., Murpree, M. (2013). Coming Back Home after the Sunrises: Returnee Entrepreneurs and Growth of High Tech Industries. Research Policy, 42(2), 391-407.

Kerr, W. R. (2008). Ethnic Scientific Communities and International Technology Diffusion. The Review of Economics and Statistics, 90(3), 518-537.

Krabel, S., Siegel, D. S., Slavtchev, V. (2012). The Internationalization of Science and Its Influence on Academic Entrepreneurship. Journal of Technology Transfer, 37(2), 192-212.

Lesińska, M., Okólski, M., Slany, K. (2014). Dekada członkostwa Polski w UE: społeczne skutki emigracji Polaków po 2004 roku. Warszawa: Wydawnictwa Uniwersytetu Warszawskiego.

Liu, X., Wright, M., Filatotchev, J., Dai, O., Lu, J. (2010). Human Mobility and International Knowledge Spillovers: Enterprises in an Emerging Market. Strategic Entrepreneurship Journal, 4(4), 340-355.

Marmolejo-Leyva, R., Perez-Angon, M. A., Russell, J. M. (2015). Mobility and International Collaboration: Case of the Mexican Scientific Diaspora. Plos One, 10(6).

Meyer, J.-B. (2001). Network Approach Versus Brain Drain: Lessons from the Diaspora. International Migration, 39(5), 91-110.

Miguelez, E. (2014). Inventor diasporas and the internationalization of technology. CReAM Discussion Paper Series, 25/14.

Miguelez, E., Fink, C. (2013). Measuring the International Mobility of Inventors: A New Database. WIPO Working Paper, 8.

Murakami, Y. (2014). Influences of Return Migration on International Collaborative Research Networks: Cases of Japanese Scientists Returning from the US. Journal of Technology Transfer, 39(4), 616-634.

Nanda, R., Khanna, T. (2010). Diasporas and Domestic Entrepreneurs: Evidence from Indian Software Industry. Journal of Economics \& Management Strategy, 19(4), 991-1012.

Oettl, A., Agrawal, A. (2008). International Labor Mobility and Knowledge Flow Externalities. Journal of International Business Studies, 39(8), 1242-1260.

Okólski, M. (2009). Polska jako aktor na europejskiej scenie migracyjnej. In: M. Duszczyk, M. Lesińska (eds.). Współczesne migracje: dylematy Europy i Polski (pp. 7-14). Warszawa: Ośrodek Badań nad Migracjami.

Saxenian, A. (2002). Silicon Valley's New Immigrant High-Growth Entrepreneurs. Economic Development Quarterly, 16(1), 20-31.

Saxenian, A. (2005). From Brain Drain to Brain Circulation: Transnational Communities and Regional Upgrading in India and China. Studies in Comparative International Development, 40(2), 35-61.

Wang, D. (2015). Activating Cross-Border Brokerage: Inter Organizational Knowledge Transfer through Skilled Return Migration. Administrative Science Quarterly, 60(1), 133-176.

WIPO Statistical Country Profiles, http://www.wipo.int/ipstats/en/statistics/country_profile/profile.jsp?code=PL.

WIPO Statistics Database, https://www3.wipo.int/ipstats/pmhindex.htm?tab=pct. 